\title{
COLONIAL CITY PLANNING IN PENANG WITH A SPECIAL REFERENCE TO THE GOVERNMENT BUILDINGS
}

\author{
A.S. HASSAN \& M.H. ABDUL NASIR \\ School of Housing Building and Planning, Universiti Sains, Malaysia
}

\begin{abstract}
Colonial buildings and monuments are the prominent symbolism of the architectural sovereignty over the existing local architecture of the conquered lands. Specifically referring to the British colonialism, the colonial architecture was disseminated to manifest the triumph of the British colonial governance and the thriving monetary economy. In examining the impact of the British colonial influence on the local architecture precisely driven by the British colonial governance and the thriving monetary economy, the study enlisted three case studies of government office buildings located in the city of George Town. These prominent case studies include the Penang Council State Assembly, the Town Hall and the High Court Building. The design coherence of these buildings in regard to the British colonial references became the essential requisite in the selection of these case studies. Analysis on the design elements of these case studies was meticulously undertaken to draw relevant relationship between the colonial design praxis and the local government office buildings. The outcome of the study underscores the profound influence of the classical style in representing the British institutional status and its monetary economic success. Intended to showcasing the grandeur of classical elements, the embodiment of classical orders such as Doric, Ionic, Tuscan and Corinthian columns is evident in abundance of institutional and financial buildings across the Peninsula Malaysia, tracing its design references to the ancient Greeks and Romans. Further stipulation on some of these buildings revealed the adornment of Greek pediments and a series of Roman arches and vaults intended to further uphold the notion of the British colonial success.
\end{abstract}

\section{INTRODUCTION}

Colonial buildings and monuments, the emblem to herald the architectural sovereignty over the pre-existing local architecture of the conquered lands, are invariably touted with the triumph of colonial governance and economy [1]. During the Western colonial era, the architectural style became the hallmark to calibrate success, triggering multitudinous construction of the colonial buildings, particularly in the provinces governed by the European nations. Consequently, the style began emanating into different periphery of the colonial worlds, with greater distribution of the style signalling greater success. This echoes the British colonialism, hailed for its major imperial conquest over the New World (America), Africa and Asia. The British imperial power began disseminating the architecture that conjures the image of British Supremacy as described by Morris [1] asserting that the British 'had ruled a quarter of the earth's land surface and nearly a quarter of its people' [2]. He further aggrandized the British colonialism, elaborating that its colony borders from 'tremendous mountains, wide and barren plains, lush pasture-lands, rain forests, and marshlands to palm beaches, bogs, grassy uplands and desert subcontinents'.

\section{LITERATURE REVIEW}

The architectural styles of colonial buildings and houses were designed in grotesquely dissimilar fashion from one province to another, in response to wide-ranging regions and climate. The British colonialists were responsible in orchestrating the dissemination of the newly 
fashioned architectural style, a product of cultural blend between the Western architectural styles predominantly ingrained to the Western European design attitudes morphed into the lesser pre-existing traditional styles of the subjugated colony [3]. The style typically renders the melange into projecting the overt dominance of the architectural styles of the West, ideally enforcing compliant to European construction standards, coupled with the introduction of newly conceived colonial cutting-edge construction technology. Ultimately, the colonialstyle buildings began showcasing the advance construction materials such as steel structure, masonry and stone artwork, which were alien to the locals. Due to the lack of knowledge of these materials, the immediate ramification presented design and constructional challenges to the local builders, a gamut which could be equally juxtaposed to the struggles of the British architects in dealing with local materials particularly timber-based materials prior to constructing the local traditional buildings and houses [4].

\subsection{Symbol of democracy}

The British imperial architecture had imposed great influence on their conquered lands, a colonial practice which reverberates the design and political praxis introduced by the Romans throughout their empire as argued by Morris [2]. The classical styles which were considered emblematic to the Western ideals of democracy and the capitalist economy became the prominent character to the buildings and monuments. The classical architecture, which predates ancient civilizations, upholds the notion of democratic superiority tracing its design praxis to its ancient Western predecessors, the Greeks and the Romans [5]. The British embraced the classical design, but unlike the Roman imperialism, the British had no intention to implement the classical styles to all buildings, monuments and houses; instead the inherited architectural practices were systematically integrated with the local architecture in the conquered lands. In some of the British colonies like America, Australia, South Africa and New Zealand, the neoclassical style became the dominant architectural influence. Unlike the rest of the conquered colonies, these British dominions were treated by the British as part of their allies. These new territories were given the privilege as permanent settlements for the British emigrants most notably from England, Wales, Scotland and Ireland, who were incessantly endeavouring for new opportunities in the New World. Conversely, nascent to the British colonial establishment, the conquered provinces like Malaysia were only regarded as a temporary settlement, with sole commitment in harnessing the local economic resources.

The decades that followed began to witness the tremendous shift in the British colonial attitudes towards the Peninsular Malaysia, envisioning the province as a prosperous melting pot, an impetus to engender profitable economy by exclusively harnessing its natural and agricultural resources [1]. The province which was previously regarded by the British authorities as remote and exotic ceased to play its function as temporary settlements, establishing a more profound role as the land of the opportunity. The immediate aftermath oversaw grand buildings and lavish monuments deliberately constructed by the British to explicitly signalling their intention for permanent settlement as they began to view the Peninsula Malaysia as their homeland. The construction of grand and aesthetic institutional buildings and monuments gradually sprung across towns and cities in the Peninsula Malaysia, with the classical style dominating the overall composition, a testament to the British institutional status and economic achievement. The embodiment of the British design and aesthetic ideals of their picturesque homeland alongside the Western colonial allegory is physically manifested through 
the interplay of classical building elements dating back predominantly to the Ancient Greeks and the Ancient Romans. Multitudes of these erected buildings are visually distinguishable by its perfectly symmetrical paragon embroidered with classical pillars typically of Ionic, Doric and Corinthian columns among others. The Greek pediments, a series of Roman arches and reiterated vaults can seldom be seen incorporated into the design of these erected buildings to amplify the symbolism of the colonial triumph $[6,7]$.

\subsection{Symbol of trade}

Aside from democracy, the colonial architectural influence is also essentially marked by the triumph of the Western economic influence over the colonized dominions. With the capitalist system became the burgeoning force for the monetary economic achievement in the colonial administration, the repercussion has greatly expedited the rise of multinational financial institutions and commercial companies involved in trades. During the colonial period of the Peninsular Malaysia, the British inaugurated the monetary economic system based on the colonial agricultural products which were uncustomary to local people. Under this system, the newly introduced colonial agricultural commodities such as rubber, cocoa, palm oil and natural resource of tin mining industry began to inadvertently eclipsing the pre-existing traditional rural paddy-growing and fishery activities. The evolution of the port cities became the impetus to trade these commercial products as chronicled by Galantay [8]:

The colonial towns of pre-industrial societies were founded in response to an enlargement of the mercantile sector which provided the risk capital for the colonising venture. The creation of mining towns and of administrative centres was simply instrumental to the achievement of the main goal of expanding long distance trade. [...] into the design of these erected buildings to amplify the symbolism of the colonial triumph.

The British fascination with the monetary system has led to the creation of a more prosperous colonized Peninsula Malaysia, transcending the British colonial economic institution as the monetary system became the chief source of the administration's profit. The outcome of this bountiful economic prosperity inevitably reinforced the position of the British administrative, financial and commercial institutions under the control of British East Indian Company. In return, the British officers received better monthly wages and subsequently improved their living standards and employment status. The immense fortune aligned with economic prosperity of the province had certainly altered the Western long-standing callous perception as they began recognizing the potential of their conquered province to transform into a prosperous Peninsula Malaysia [1]. The port city of George Town, the prominent testament of economic prosperity in the province, developed into the busiest trading centre in the Southeast Asia. The city significantly grew into a major trading centre, where the waterfront areas became the epicentre of the major trading affairs made popular by its bustling commercial activities of import and export of the merchandise goods. The waterfront channels were the most densely built-up areas in the city typified by an agglomeration of administrative offices, financial institutions, warehouses and commercial shop houses due to its direct involvement in trades. Administrative offices like the custom building were strategically nestled within the midst of harbour complexes to figuratively empower the government control over the trading activity. 
Historically the City of George Town is the oldest British colonial city in Malaysia as well as in Southeast Asia with the city's name tracing its origin to the infamous English monarch King George III, made notorious for his majestic reign in the era of British colonialism [9]. Today, the historical City of George Town developed to become the second largest city in Malaysia. The city which was established in 1786 was originally a small town resided by a small group of people. Prior to its establishment, the city was initially introduced as the British trading centre in Southeast Asia under the authority of Captain Francis Light [10]. $\mathrm{He}$ anticipated the island as an ideal selection to flourish as port city acknowledging the island's strategic geographical location as a trading centre. Over the next few years following the establishment, the port city of George Town underwent a progressive sprawling of warehouses, built primarily to store merchandise goods alongside commercial shop houses acting as the trading offices. The major streets at the waterfront areas were divided into two major trading zones namely the eastern and the western streets. The western part of the street was designed to accommodate the Weld Quay's important buildings while the eastern part, in reverse, is specifically referring to the harbour full of small sailboats to bolster the transfer of merchandise goods from the ship to the warehouses. The warehouses consisted of an extensive array of shop houses are commonly constructed out of bricks and cement as the primary materials. Elaborate classical Roman arches seemingly adjoined each unit of the shop houses allowing the creation of five-foot walkways, windows and doors [11]. During the colonial era, the shop-like warehouses mainly served as offices for the European companies like shipping agents, general importers and tin refiners [7].

The Beach Street which is ideally situated one block away to the west of Weld Quay was a setting of numerous shop houses essentially to house traders and forwarding agents. It was a melting pot for various ethnic communities chiefly the Malay, Chinese, European and Indian traders who provide their expertise in various trading affairs including cargo handlers and shipyard workers. Furthermore, it was the venue for commercial products and merchandise goods to be temporarily stored in several warehouses before they were finally transported to their respective trading destinations. The Beach is also the home of major European financial institutions such as the Standard Chartered Bank, the Algemene Bank Nederland (ABN AMBRO Bank) and the Hong Kong and Shanghai Banking Corporation which are mostly located at the end of the street. The location of the government buildings such as post offices, Penang Council State Assembly, Immigration Building, City and Town Halls, and Magistrate Buildings can be seen standing further to the north.

\section{RESEARCH METHODOLOGY AND THE CASE STUDIES}

This study is to identify neoclassical elements in portraying image of colonial building in George Town, Penang. Among the significant elements are as follows: (Table 1)

To provide fundamental understanding of the colonial influence, this study enlists three government office buildings in the city of George Town with their neoclassical elements as follows:
a. Penang Council State Assembly
b. Town Hall
c. High Court Building 
Table 1: Architectural elements and the definition.

\begin{tabular}{|c|c|}
\hline $\begin{array}{l}\text { Architectural } \\
\text { element }\end{array}$ & Definition \\
\hline Arcade & A sequence of arches structures emerging as a covered walkway. \\
\hline Architrave & A lintel or beam sitting atop capitals of the columns. \\
\hline Balcony/veranda & $\begin{array}{l}\text { A projected floor several feet over the building wall creating a shade } \\
\text { beneath it and open door system for natural indoor air movement. }\end{array}$ \\
\hline Balustrade & $\begin{array}{l}\text { A moulded lathe-built form made out of stone, wood or metal, incor- } \\
\text { porated on the footing of parapet wall or integrated as the handrail of a } \\
\text { staircase. }\end{array}$ \\
\hline Bay & $\begin{array}{l}\text { An extended division of exterior or interior of a building by an array of } \\
\text { windows, vaults, arches, roofs, etc. }\end{array}$ \\
\hline Classical column & $\begin{array}{l}\text { A column with a round or a square base crowned with Doric, Ionic or } \\
\text { Corinthian capital. }\end{array}$ \\
\hline Colonnade & $\begin{array}{l}\text { A set of reiterated columns joined by an entablature or a beam, in free- } \\
\text { standing manner or directly integrated into a building. }\end{array}$ \\
\hline Cornice & An arrangement of ornate mouldings fixed to a wall, arch, etc. \\
\hline Cupola & $\begin{array}{l}\text { A minimal size dome structure on top of a building or adorned as a } \\
\text { crown topping a larger dome. }\end{array}$ \\
\hline Dentil & $\begin{array}{l}\text { A pack of rectangular blocks resembling teeth frequently embellished } \\
\text { under the soffit of a cornice. }\end{array}$ \\
\hline Fan-like window & $\begin{array}{l}\text { An upper semicircular or semi-elliptical window often fixed with sash } \\
\text { bars resembling a set of fan ribs mostly secured on top of a door or } \\
\text { another window. }\end{array}$ \\
\hline Keystone & A wedge-shaped stone cast slit into the crest of a masonry vault or arch. \\
\hline Parapet wall & $\begin{array}{l}\text { A low-projected wall runs vertically along the edge of the building/ } \\
\text { house particularly in the classical and modern architecture to replace } \\
\text { the overhang roof system. There is a roof gutter design behind the } \\
\text { parapet wall. }\end{array}$ \\
\hline Pedestal & $\begin{array}{l}\text { A base of a column constructed slightly bigger than the diameter of its } \\
\text { respective column and risen several foot above the ground. }\end{array}$ \\
\hline Pediment & $\begin{array}{l}\text { The initial design is a triangular wall section fixed above the entabla- } \\
\text { ture supported by columns. The design gradually evolved into different } \\
\text { shapes most notably semicircular and rectangular section during the } \\
\text { neoclassical period. }\end{array}$ \\
\hline Pilaster & $\begin{array}{l}\text { A slightly protruded column built as integral part of a wall manifesting } \\
\text { a rendition of a supporting column. }\end{array}$ \\
\hline Pitch roof & $\begin{array}{l}\text { A roof with a slope over an angle of } 20^{\circ} \text { defined by Malaysian Uniform } \\
\text { Building By-Laws. }\end{array}$ \\
\hline $\begin{array}{l}\text { Porte-cochere/ } \\
\text { portico }\end{array}$ & $\begin{array}{l}\text { A sheltered porch or portico primarily utilized to drop passengers from } \\
\text { vehicles or horse carriages (in colonial times) and to provide protec- } \\
\text { tion from weather and can be found either on the main or secondary } \\
\text { entrance. It is often integrated with open veranda/balcony on its top. }\end{array}$ \\
\hline
\end{tabular}


Quoins A set of masonry blocks arranged vertically at the corner of a wall symbolizing permanence and strength, and reinforcing the immediate impression of structural presence.

Recessed wall A wall recessed several feet from the building wall to give a shade from direct sunlight and rainwater. Known as 'serambi' in traditional Malay architecture.

Roof overhang A projected roof design several feet over the building wall creating roof shades from direct sunlight and rainwater.

Round arch A curve-shaped masonry construction used to span an opening alongside to support the mass on top of it.

Shuttered window A window with angled horizontal slats to permit indirect sunlight and natural air ventilation, restricting rain and direct sunshine.

Tympanum A decorative semicircular or triangular wall surface right on top of an entrance encapsulated by a lintel or arch.

\subsection{Penang council state assembly}

Standing magnificently to the neighbouring historical site of Fort Cornwallis at Sultan Azlan Street, the Penang State Assembly overlooks the refreshing grounds of the Padang Kota Lama. The monument was erected in 1905 at the height of the British colonial era, is placed under the authority of the state government and is presently serving as an Assembly Hall for the Penang State Parliament. The immediate impression of the Assembly Building echoes the influence from the ancient Greek temples most notably the Temple of Concord, the Temple of Poseidon and the glorious Parthenon. Upon closer inspection, the design elements draw similar parallels to the 'Doric Order' of the Greek prostyle temple model plainly visible through the embodiment of six inviting Doric columns at the front of the main buildings to support the roof structure. The main entrance of the State Assembly are chaperoned by two alternative entrances which protruded from the main building further injecting the image of the Greek temples. The facade is embellished with colossal Doric columns with a strikingly modest triangular crown roof resting atop the supporting columns (Fig. 1).

In contrast to typical Greek temples, the State Assembly completely obliterated the solid platform often merged with three large steps (stylobate and stereobate). This is due to their steepness and proportion which makes it uneasy to users to climb these steps. In exchange, a set of three smaller cascading steps made proportional to human scale was constructed a few feet away from the front colonnades to offset the missing design elements. The absence of a platform allowed for the columns to be directly built from the ground and secured by cubicle bases, a construction method with resounding similarity to the typical column system of a traditional Malay house, where the columns are often supported by a base known as the piles. The extended roof is rendered with clay tiles projecting overhangs to pragmatically delivering shades to adapt the thermally demanding tropical climate. The exterior walls are furnished in subtle white complexion encompassing minimal openings of approximately 9-10 feet above the ground floor. The building is festooned with nine wooden entry doors to hasten the access for the state representatives during the state assembly. The solitary rendition of its minimal openings engendered an efficient privacy status an essential requisite to properly function as the State Assembly. 


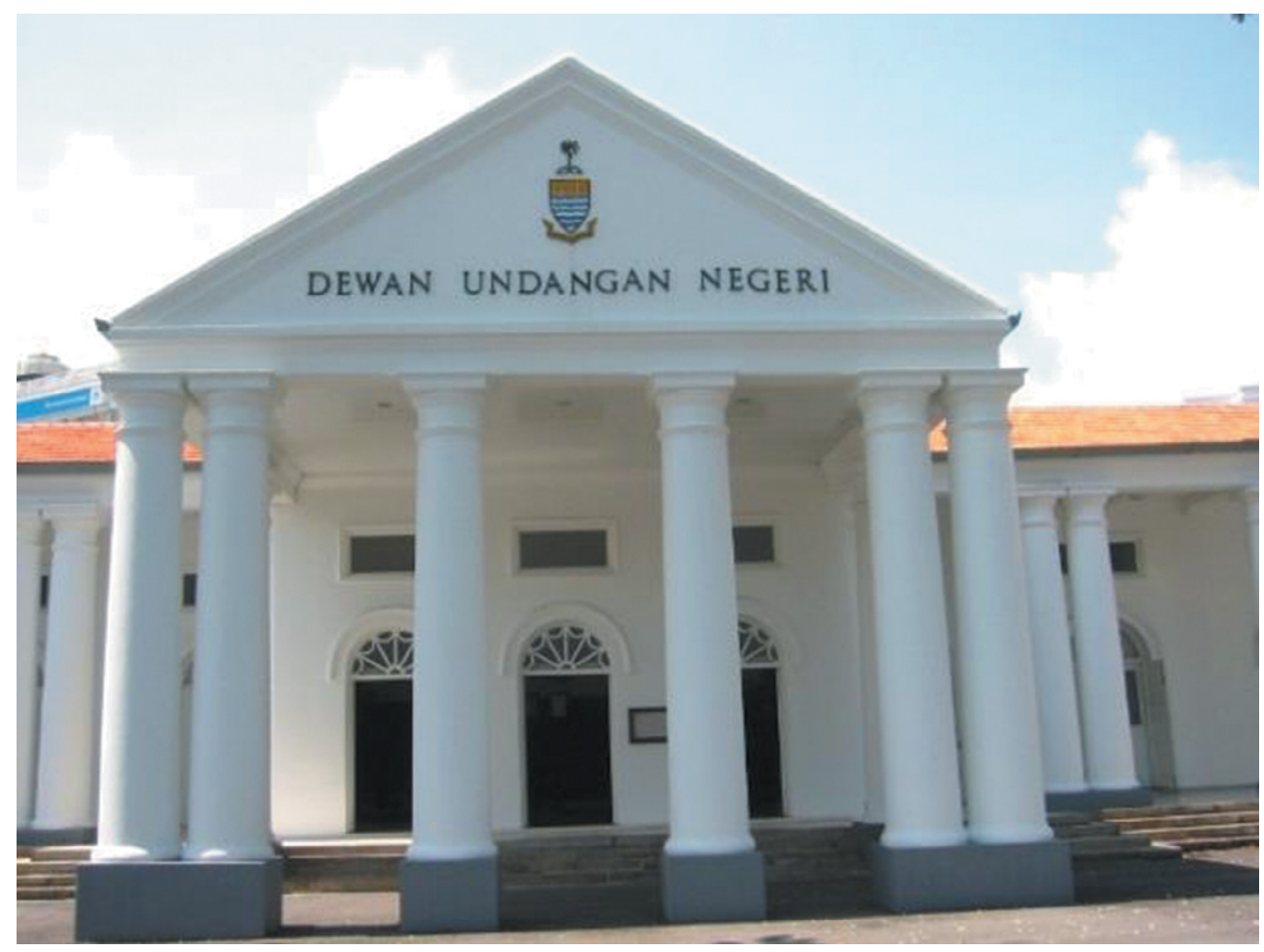

Figure 1: Penang Council State Assembly.

\subsection{Town Hall}

The Town Hall which was constructed in 1850 had undergone several renovations from 1904 to 1906 , and is currently serving as the municipal hall under the supervision of the Penang Municipal Council (MPPP). The majestic rendition of the two-storeyed building using a mixture of white and gold yellowish paints emboldens its colonial reference with vast tendencies towards the neoclassical style. In response to its purely symmetrical plan layout and elevation, the resulting facade expresses design affiliations to the prostyle portico style at the middle and joint by double symmetrically balanced projected bays. On the ground floor, the portico is harmoniously integrated with three open arches, and its apparent dominant central arch is constructed to be slightly taller and wider than the side arches. The portico is articulated with minimally ornate double Tuscan columns on pedestal support in each corner enhanced by two columns at the centre that compose the arches. An indistinct single entrance arch on each side of the portico compliments the Tuscan columns and arches. The upper level is injected with a balcony with the largest single arch spanning at each side of the extended facade. Among the striking traits of this building is the degree of ornamentation that encapsulates the entire facade complexion of the building. It ranges from its meticulously ornate floral motifs on the pediment, a magnificent array of balustrades skirting the unbroken appendage of its cornices and the Tuscan pilasters seemingly dividing the upper and lower levels. The flamboyant melange that ensued is perpetuated by its two immediate bays through the embodiment of moulded arches, decorative keystones and double-leaf glass windows (Fig. 2). 


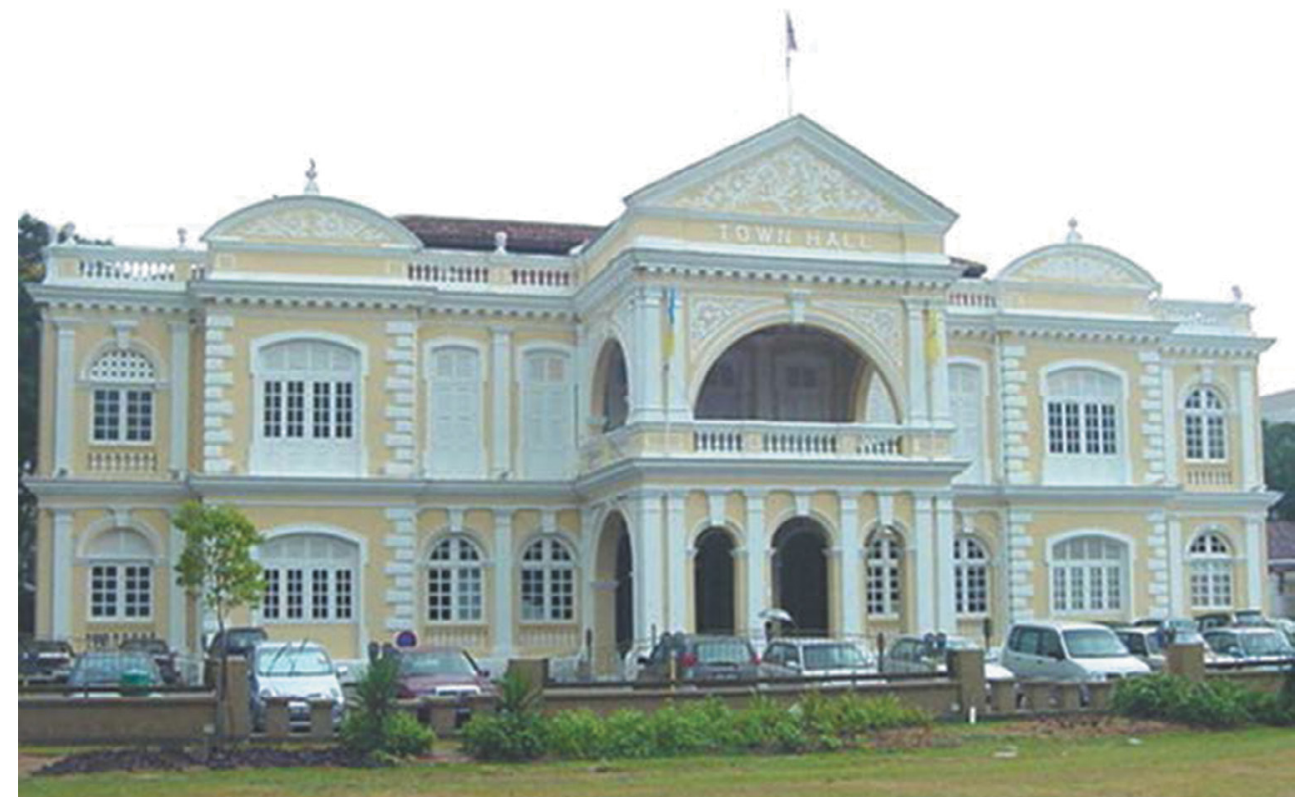

Figure 2: Town Hall.

\subsection{High Court Building}

The High Court Building which is located at Light Street, in George Town, was constructed in 1905 and is currently placed under the authority of the Federal Government. The facade of the two-storey courthouse is rendered in gold yellowish colour articulated with an alternate of white-coloured stripes legibly manifesting strong design tendencies to the neoclassical architectural style. The symmetrical plan layout of the courthouse divides the building into four sides, with each side carrying a prostyle portico. On the ground floor, the portico is constituted of three bays by a set of double classical columns supporting the delicate glass louvered shutter windows. Each of the rectangular windows is complement by the geometrically moulded balustrade sills. On the first floor, the style evidently reiterated the classical columns in a slightly smaller scale embroidered with contrastingly darker shades of timber louvers in between the columns. The triangular pediment (tympanum) is engraved with letters 'Mahkamah Tinggi' a Malay-language expression translating 'High Court' punctuating an immediate impression of its prominent function as a courthouse.

The influx of the building's colonial design traits is also evident from the extensive colonnaded walkways on the ground floor triggered by a row of classical-style columns and the Doric capital supporting the upper floor. The purely geometric nature of its vertically arrayed columns is juxtaposed by the organic presence of the semicircular arches on the upper floor. From the spectacle of the extended bays on the side of the building, each section of the bay is divided by pilasters. Glass louvered shutters are well connected and fixed in each division of the bay. The amalgamation of geometrically simplified classical building configurations of the main facade and the side bays is carefully clung to the core of the building made of octagonal turrets with copulas on all its four corners (Fig. 3). 


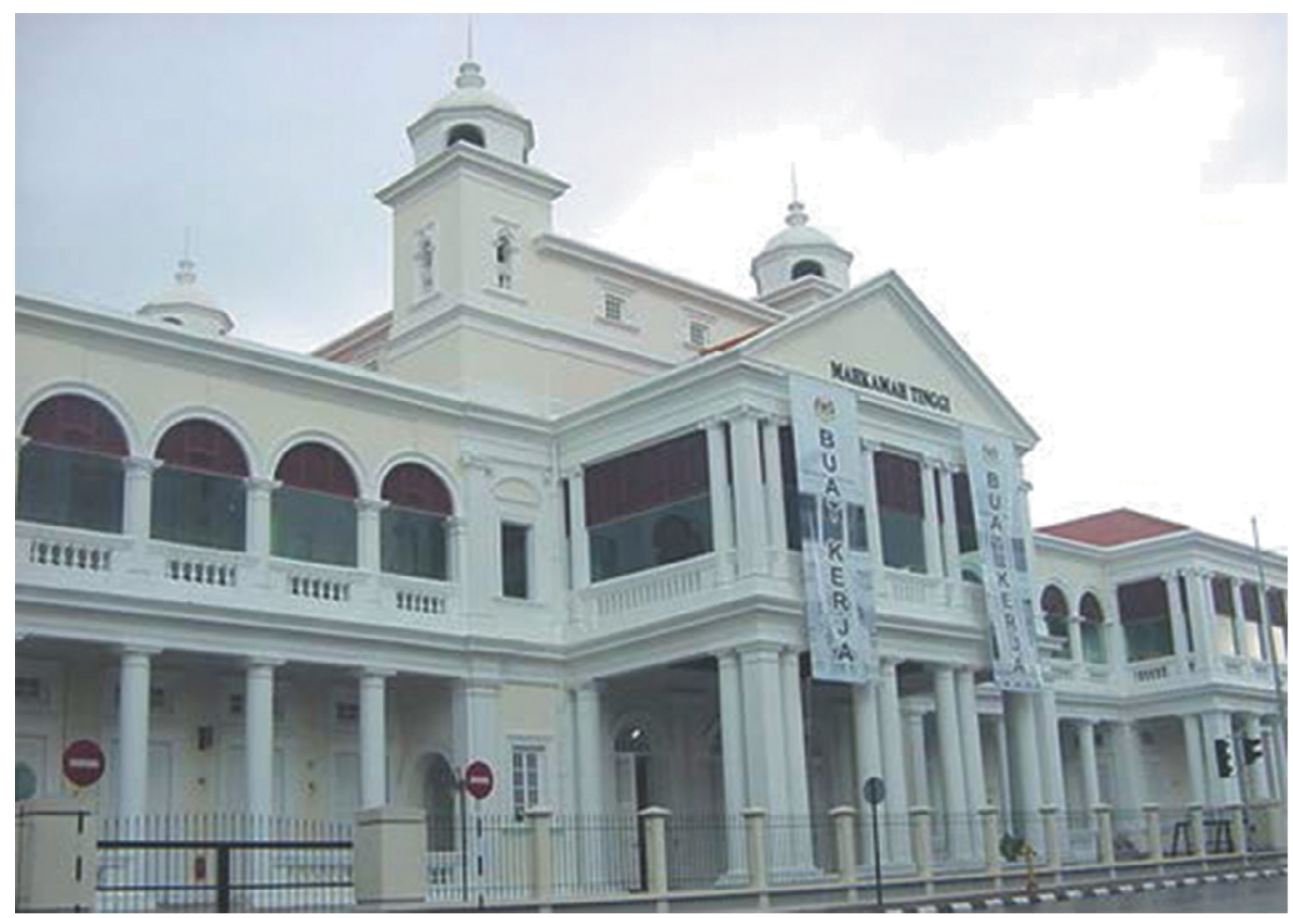

Figure 3: High Court Building.

\section{DISCUSSION}

Table 2 shows the result of the colonial design elements identified on the three case studies. The study finds the following:

1. Numerous neoclassical design elements can be found in the case studies of government office buildings with special reference to mostly the classical Greek and Roman styles.

2. Each of the case studies is designed with a porte-cochere or portico as the central facade which engendered facade design with roof shade coherence to the tropical climatic contexts with harsh sunlight and heavy rainfall. Through this method a number of overriding neoclassical design elements can be traced in each of the case studies.

3. In all case studies, the porte-cochere or portico is fundamentally designed with a pedestal as platform to support the classical columns. The supporting columns, which divide the portico into three facade bays, are connected to an unbroken projection of architrave with minimally ornate cornice. Unlike the rest of the case studies, the Case Study 2 (Town Hall) is further adorned in a continuous array of dentils alongside its cornice.

4. Many porte-cochere or portico designs continue to the upper floors and are finally crowned with a pediment in engraved tympanum.

5. The study suggests that round arches can be persistently found in all the case studies that constitute to the design of the classical bays. Keystones can be found attached to the crest of the arches only in Case Study 2.

6. In Case Study 3 (High Court) the round arches form an arcade, a design element which disparate the high court with the other case studies. 
7. In Case Studies 2 and 3, the embodiments of classical elements like balustrades, shuttered windows, pilasters and parapet wall are evident, while colonnade and fan-like windows are profoundly utilized in Case Studies 1 and 3.

8. Additionally, unlike Case Studies 1 and 3, the Town Hall facade is decorated with quoins to draw reference to immense structural strength.

9. A set of cupolas can only be found on Case Study 3 and is rendered unavailable to the other case studies.

10. The incorporation of climate-responsive design elements is observable with application of portico/porte-cochere, balcony/veranda, pitch roof, roof overhang, recessed wall, fanlike and shuttered window as a design adjustment to the tropical climate for shades and natural air ventilation to provide thermally comfortable environment.

Table 2: The result of analysis of the architectural elements.

\begin{tabular}{lccc}
\hline Architectural elements & State Assembly & Town Hall & High Court \\
\hline Arcade & & & $\mathrm{X}$ \\
Architrave & $\mathrm{X}$ & $\mathrm{X}$ & $\mathrm{X}$ \\
Balcony/veranda & & $\mathrm{X}$ & $\mathrm{X}$ \\
Balustrade & & $\mathrm{X}$ & $\mathrm{X}$ \\
Bay & $\mathrm{X}$ & $\mathrm{X}$ & $\mathrm{X}$ \\
Classical column & $\mathrm{X}$ & $\mathrm{X}$ & $\mathrm{X}$ \\
Colonnade & $\mathrm{X}$ & & $\mathrm{X}$ \\
Cornice & $\mathrm{X}$ & $\mathrm{X}$ & \\
Cupola & & & $\mathrm{X}$ \\
Dentil & & $\mathrm{X}$ & $\mathrm{X}$ \\
Fan-like window & $\mathrm{X}$ & $\mathrm{X}$ & $\mathrm{X}$ \\
Keystone & & $\mathrm{X}$ & $\mathrm{X}$ \\
Parapet wall & & $\mathrm{X}$ & $\mathrm{X}$ \\
Pedestal & $\mathrm{X}$ & $\mathrm{X}$ & $\mathrm{X}$ \\
Pediment & $\mathrm{X}$ & $\mathrm{X}$ & $\mathrm{X}$ \\
Pilaster & & $\mathrm{X}$ & $\mathrm{X}$ \\
Pitch roof & $\mathrm{X}$ & $\mathrm{X}$ & $\mathrm{X}$ \\
Porte-cochere/ Portico & $\mathrm{X}$ & $\mathrm{X}$ & $\mathrm{X}$ \\
Quoins & & $\mathrm{X}$ & \\
Recessed wall & $\mathrm{X}$ & $\mathrm{X}$ & \\
Roof overhang & & & \\
Round arch & & & \\
Shuttered window & & & \\
Tympanum & & & $\mathrm{X}$ \\
\hline
\end{tabular}

\section{CONCLUSION}

In conclusion, the colonial buildings and monuments are evidently utilized as the insignia of colonial architectural sovereignty over the existing local and expatriate architecture in their overthrown dominions. This praxis is undoubtedly employed to manifest the triumph 
of the British colonial governance with thriving monetary economy. Retrospectively, the fostered economic prosperity had presumably shifted the erroneous and long-established British perception of the Peninsular Malaysia. The province which was previously regarded as temporary settlement for the British emigrants promptly began to induce profitable monetary economy in agriculture and natural resources signalling economic prosperity. The fruitful province ceased to exist as a remote and exotic terrain at the sight of the British officers. The shift in the British colonial attitudes witnessed the sprawling of grand buildings and monuments indicating their inclination for permanent settlement in the newly conceived land of the opportunity.

Institutional and financial buildings and monuments were built with precise intention in showcasing the grandeur of classical style with adjustment to the local tropical contexts across the towns and cities in the Peninsular Malaysia. The classical style was chosen as the ideal style for representing institutional status and its monetary economic success. The ultimate design ramification observed the embodiment of classical elements profoundly the classical pillars such as Doric, Ionic, Tuscan and Corinthian columns into the colonial buildings and monuments. Some of these buildings revealed the unity of Greek pediments and a series of Roman arches and vaults intended to amplify the notion of the colonial success. Application of portico/porte-cochere, balcony/veranda, pitch roof, roof overhang, recessed wall, fan-like and shuttered window is feasible for shades and natural air ventilation to provide thermally comfortable environment. The design creates a unique hybrid of colonial building that can only be found in this region [13].

\section{REFERENCES}

[1] Morris, Jan, (ed.), 'In quest of the imperial style,' Architecture of the British Empire, Weidenfeld and Nicolson: London, 1986.

[2] Morris, Jan, Stones of Empire, Oxford University Press: Oxford, 1983.

[3] Abel, Chris, 'Living in a hybrid world,' Design Policy: Proceedings of the 1982 Design Research Society Conference, R. Langdon and N. Cross: London, 1985.

[4] Dumarcay, Jacques, The House in South-East Asia, Oxford University Press Pvt. Ltd.: Singapore, 1987.

[5] Hassan, Ahmad Sanusi, (ed.), 'Colonial houses in peninsular Malaysia,' Contextual Issues of the Built Environment in Malaysia, USM Press: Penang, 2009.

[6] Jessup, Helen, 'The Dutch colonial villa,' MIMAR, 13th ed., Concept Media Pvt. Ltd: Singapore, 1984.

[7] Kohl, David G., Chinese Architecture in the Straits Settlements and Western Malaya: Temples, Kongsis and Houses, Heinemann Educational Books (Asia) Ltd.: Kuala Lumpur, 1984.

[8] Galantay, Ervin Y., Newtowns: Antiquity to the Present, George Braziller Inc.: New York, 1975.

[9] Hassan, Ahmad Sanusi \& Che Yahaya, Shaiful Rizal, Architecture and Heritage Buildings in George Town. Penang, USM Press: Penang, 2012.

[10] Salleh, Badriyah, Historic Centres of Melaka and Penang: Social and Cultural History, Unpublished Articles for Enlisting Penang and Malacca UNESCO World Heritage Lists, Penang, Malaysia, 2001.

[11] Emrick, Micheal, 'Vanishing Kuala Lumpur: The Shop house,' Majalah Arkitek (the Journal of the Malaysian Institute of Architects), Persatuan Arkitek Malaysia: Kuala Lumpur, vol. 2, 1976. 
[12] Salleh, Badriyah, Melaka and Penang: Culture of Tolerance, Peace, Diversity, Conflict and Continuity, Unpublished Articles for Enlisting Penang and Malacca UNESCO World Heritage Lists, Penang, Malaysia, 2001.

[13] Abel, Chris, 'Regional Transformations,' Architectural Review, The Architectural Press Ltd.: London, November 1986. 